\title{
THE DIFFERENCES BETWEEN ARSIPARIS AND INDEPENDENT PROFESSIONAL RECORD MANAGER
}

\author{
Ike Iswary Lawanda \\ Fakultas Ilmu Pengetahuan Budaya, Universitas Indonesia \\ Correspondence: iswari@ui.ac.id
}

Diajukan: 11-08-2018; Direview: 02-11-2018; Diterima: 25-11-2018; Direvisi: 28-11-2018

\begin{abstract}
ABSTRAK
Artikel ini mengargumentasikan adanya istilah archivist sebagai istilah yang digunakan di luar Indonesia tidak dapat begitu saja disamakan dengan arsiparis, di tengah pengertian globalisasi dan profesionalisasi. Archivist dan arsiparis berbeda dalam status kebebasan dan hubungan di dalam institusi pemerintahan, walaupun keduanya berada dalam gabungan kegiatan. Metode penelitian aksi berpartisipasi (PAR) digunakan sebagai jalan masuk dan mendekati komunitas. Metode ini menekankan pada partisipasi dan aksi yang dilakukan peneliti dengan para subjek pelaku dalam komunitas. Metode ini berupaya memahami dunia agar dapat membuat perubahan bersama secara kolaboratif disertai dengan refleksi yang terus menerus dilakukan peneliti. Informan adalah tujuh orang pengelola rekaman pengetahuan di Indonesia. Dalam membangun argumentasi, akar kelahiran dan asal usul archivist dan arsiparis. Dalam pengertian awam, ditelisik dengan kelahiran arsip di Indonesia pada tahun 1950an dan pertumbuhan dan perkembangan arsip selama dekade selanjutnya, menyiratkan kesamaan dalam kegiatan kerja seputar pengelolaan rekaman pengetahuan atas setiap kegiatan kerja organisasi. Pemahaman awam ini menunjukkan adanya integritas rekod, asal usul arsip, dan aturan susunan arsip sepanjang waktu tumbuh kembang dikaitkan ke dalam satu tema tunggal yang menyatu melalui relasi-relasi antara rekod dan arsip berlangsung secara kontekstual. Arsiparis, pengelola rekod dan archivist bagaikan dua jalur pengelola dokumen organisasi di dalam suatu pemerintah yang menjunjung tata kelola. Artikel ini menguraikan kewajiban dan panggilan archivist dan arsiparis ikut serta memicu kelahiran profesional yang independen dengan sasaran dan tujuan memberi jalan bagi archivist dan arsiparis dapat diterima di dalam persaingan pasar global dan mendapatkan perlindungan dari asosiasi profesi yang independen, dilegitimasi oleh regulasi pemerintah dan undang-undang.
\end{abstract}

\begin{abstract}
In this article the author argues that the globalization and independent professionalization makes it imperative that archivists and arsiparis are engaged in a joint enterprise hence differ in the status of independence and the relationship within the government institution. This paper presents Participatory Action Research (PAR) which is an approach to research in communities that emphasizes participation and action. It seeks to understand the world by trying to change it, collaboratively and following reflection. Informants of seven record managers in Indonesia are the source of data on this research. In developing this argument, the common roots of archivist and arsiparis are examined its emergence of archives in Indonesia in the 1950s and their subsequent divergence over the next three decades. The author identifies the common ground that archivist and arsiparis share in dealing with recorded information. This common ground, which includes records integrity, archive provenance, and archive original order over time, is linked into a single unifying theme by the importance of the contextual relations. Arsiparis, record manager, and archivist are considered as two ways of managing document in organization under the same roof of governing government. The article concludes with a call for archivists and arsiparis to participate in the design of independence professionals, in order to ensure that archivists and arsiparis are acceptance within the competition of global market under the protection of independence professional association, and legitimized by the regulation of government under the constitution.
\end{abstract}

Keywords: Archive management; Archivist; Record manager; Profession; Hybrid institution 


\section{INTRODUCTION}

Arsiparis is a special functional occupation for civil servants within government organizational structure with the position to organize records in government offices. The functional position of the archivist is governed by Regulation of the Ministry of State Apparatus No. 43 in 2009 then renewed in 2014 and later revised with the objective of increasing the number of Arsiparis by Regulation No. 48 in 2016 about inpassing (integration) of the archivist.

The position of Arsiparis is considered to be equivalent to secretarial and administrative work, not a profession of professional. The functional occupation of arsiparis is obtained through socialization program and training provided by ANRI. The program and training has the objectives to gain the title of Arsiparis to the individual and to produce as many arsiparis as possible, which is clearly stated in Regulation No.48 in 2016. Arsiparis as a functional occupation has been acknowledged by the government with the provision and protection by legislation and regulation. Nevertheless professionally, arsiparis have also experienced being marginalized.

ANRI as the highest archives institution in the scale of State government that provides training to the civil servants in being arsiparis, manages the institution of archive in each government and public institutions; supervises archives management in all government institutions and all institutions within the Republic of Indonesia. Archives supervision by ANRI in non-governmental and public institutions is focused on archives physical arrangement; it does not touch the individual selves of record managers. Arsiparis are governed by the Ministry of Administrative and Bureaucratic Reform/ Kementerian Pendayagunaan Aparatur Negara (KEMENPAN) that places the Arsiparis as the support for government's organizational activities within the functional not structural domain. Thus it means that the functional occupation does not have the authority of policy making.

Currently records managers have expanded globally thus records managers cannot be separated from international network with the existing ICT access and information society demanding the organizational and records managers' openness and transparency values (McKemmish, et.al., 2011). The paper is to accommodate a discussion on incorporation between arsiparis and professional record managers in Indonesia; the different and the sameness of the two in the jobs and regulation; also, the meaning of the two in the managerial function of organization controlling.

\section{REVIEW LITERATURE}

ISO 15489 has now become the reference for the condition of professional services and products; whereas the level of records manager's profession is determined by internationally standardized competency under the control of International Certification in Management Record to meet the market's demand and need, and evidently, it is adjusted to the authority of professional association which refers to the national legislations. Global change is not necessarily about uniformity or oppression or progress; nation-states and organizations and managers are not sponges or pawns, but the way actors respond to challenges under the guidance of existing institutions (Guillén, 2001). Professional associations play an important roles in theorizing change, endorsing local actors' innovations and shaping their immerses (Greenwood, et.al., 2002).

Regardless of the difference between the arsiparis and the independent professional record manager, the provenance and original order of archives become the working principle 
even if the archives managers in the world have various ways to gain their knowledge and practices (Bettington, 2008; O'Toole \& Cox, 2008). Two principles of archives/records confirm the necessity of archives management so that they can be used effectively and efficiently.

This paper describes that archives management subjects can be categorized into arsiparis and independent professional record manager within the scope of non-government offices or beside arsiparis as civil servants. Record management is carried out in order to maintain the value of information so that it can be retrieved along with the values followed by the organization since the organizational records are part of the nation's and state's ownership. However, it is beyond conventional territorial borders instead it concerne most on humanities (Gogolou \& Dimopoulou, 2015).

\section{METHOD}

This paper presents participatory action research (PAR) which is an approach to research in communities that emphasizes participation and action. It seeks to understand the world by trying to change it, collaboratively and following reflection. PAR emphasizes collective inquiry and experimentation grounded in experience and social history. Participatory allows communities of inquiry and action evolve and address questions and issues that are significant for those who participate as co-researchers (Reason \& Bradbury, 2008). This method integrates three basic aspects of their work: participation (life in society and democracy), action (engagement with experience and history), and research (soundness in thought and the growth of knowledge) (Chevalier \& Buckles, 2013). Action unites, organically, with research and collective processes of self-investigation (Rahman, 2012). Activity, action, and operation could not be separated from social relation and community life because activity could not occur without social relation (Leontjew, 1979). Interviews during process of PAR and document study are conducted for data collation, proceed by codification and interpretation.

Action research is conducted in spiral coined which firstly account by Lewin (1946). The action research spiral is accompanied by a diagram which different authors construct their-own versions. A spiral contains of steps which then at the end comes up as a cycle. The steps include acts begin by identifying a problem or creating an idea followed by planning the action to be taken then implementing and reflecting again and again. Revision and evaluation are conducted when doing the reflections until it gets to final implementation. The stages can be overlap as a complex piece of action research evolves.

In reality the process is more fluid, open, and responsive. The research can be reach its success when participants have a strong and authentic sense of development and evaluation in their practices, their understandings of their practices, and the situations in which they practice (Kemmis \& McTaggart, 2005). Certainly, it has produced useful outcomes in the fields of interest of this research.

\section{RESULTS AND DISCUSSION}

Arsiparis in quite a lot of amount become important as archives are records of activities or events in various formats and media in accordance to information technology and communication development created and accepted by state and local government institutions, educational institutions, companies, political organizations, community organizations, and individuals. Archives are important for an organization because they assist the organization to 
meticulously recognize policies and implemented and future activities, enable the organization's community to transfer past knowledge and learning, protect the collective interests' of the community, people and nation, and fulfill the interests of the organizational objects' implementation. They also empower and save the evidence of intellectual status and potential development that create innovation and intellectual works for the interests of the internal management of the organization, people and the nation's collective memory.

Arsiparis are formed through training and development that is not in line with the quality of competence in the professionals. Archives/records specialists have different capabilities or competencies in carrying out their job. Such situation and condition caused a gap with record manager in non-governmental/private organizations and non-civil servants in governmental organizations. Most of the record managers graduate from formal education in archives; they cannot be called arsiparis, hence titled as record managers and document controllers. Record manager profession is beyond the archivist functional occupation needs and requires place to be able to present its professionalism, independence, competitiveness, and success in the midst of global market. Nevertheless, their competencies are still related for the free market that prioritizes locally, regionally, and globally acknowledged professional competencies. Record managers in industrial worlds are supported implicitly by the government act of UU No.8 in 1997 on corporate document.

Every public and private organization should never be denied to have explicitly and implicitly labeling of personals whom in charge to manage the records of an organization. Whether records in the meaning of UU No.43 in 2009 or records in the meaning of theoretical concepts that we may find in text books and journals on records and archives. Those personals in charge in records management of an organizations and corporation have undertake such an important position in its organization in term of good governance policy being recognized in every countries all over the world including Republik Indonesia.

Governance as a concept implied in the government encourage and urge all of the organizations in any forms to be transparence and accountable. Thus, in pursuing this requirement records become a way to manifest the goal. It is not easy for record managers in Indonesia to get their status and recognition as the only label which is known by some people in Indonesia, is only arsiparis. They become so popular and in so much need within the scope of public organizations but in part they are nowhere in their status of profession that they have been carried on all of these times, along with arsiparis which has the position in the structure of government. This dilemma have been faced by many personal record managers in Indonesia, they do not know what to do to get solution of their status. They seem fear to speak out and give voice to their neglected professions in this democratic country. They do not know where to turn to and they just accept their situation and condition concerning their roles and status in equilibrium.

All these times, they rely and support on each other in their interaction to each other. Sometime, a few of them meet up in order to hang out just to have chit chat in the informants own words, hence actually when the author listened to the stories of those actors consist of meaningful contents of their chit chats contain of deep and inspiring knowledge and information. They share not only information concerning their jobs but also new development of knowledge in this learning area from their experiences. Those experiences and knowledge of record manager practitioners hardly can be found in the public organization by arsiparis. As arsiparis work of managing public organization archives depend on and in the framework 
of ANRI. Anyhow, record managers still survive in their-own capacity without any support from the government. They just concentrate on the works and organization goal.

The works they do and perform are so dynamic and challenging in term of organization existence and prospect in the future. They do the works of managing organization records catching up with rapid development of information technology. Technology of information in the work of record management is necessary as each activity and acts produce working papers which become the evidence of work and information. The values of their works and information contain in the working papers are not just evidential but more than that, they drive organization performance to reach their goals.

\subsection{Record Manager Position in Indonesia}

This creates the urge of the profession's certification institution. Additionally, nongovernmental organization and private organizations have archive managers or document controllers or record managers who need a vessel so that their professionalism can be accepted and appreciated in accordance with the prevailing standards. The record managers and other names are used for in the term of it give their voice which has been in silent notion all these times that they also do their works and jobs managing organizations and institutions' documents based on the principle of original order and provenance with integrity. However, they have not being acknowledged and recognized in term of the regulation and arsiparis which belong to functional occupation in the government structure of Republik Indonesia. In term of archivist framework of profession, and conception, they are included in the term and become a part of the inclusion.

In this era of governance which has been applied in Indonesia, we are encouraged to be more sensitive and strategic enhance the independence professionals such as record managers. The actors of record managers share their aspiration and voices to found the association of their professional which they have made a check in BNSP beforehand and ask for permission to the representative of ANRI long before. They have apparently founded the association called Perkumpulan Profesi Pengelola Rekod Indonesia (P3RI). Anyhow, as they are also the stakeholders of ANRI and the other way round, they ask for legitimate protection by the government through its constitution referring to law on arsiparis in 2009. The record manager certification accommodates the gap marginalization experienced by archives managers in nongovernmental/private organizations and those in the governmental organizations who are not civil servants. The certification institution produces professional and independent archive manager profession. Competency, in addition to development and socialization that have been applied to arsiparis all these time, becomes the foundation in producing independent professionals. The competency completes the existing archivist functional training carried out by ANRI. The institution sets the target of producing certification under the guidance and control of the National Professional Certification Board (Badan Nasional Sertifikasi Profesional/BNSP).

\section{To support the strategic plan, I propose:}

- To carry out a program to produce professional and independent archive manager certifications. The professional certification consists of a frame of competency, competency test material, and professional competency certification. Record manager professional competency frame is an innovation since it is a combination of the existing archivist competency and the archives management's international standards. 
- The certification product gives certification services adopting American Record Manager Association competence guide, covering trainings for four levels of competency: skills, knowledge, ethics, and personal psychology, each of which consists of 5 (five) competency units (ARMA, 2007). A competency test is given for each level (with the module, guide book, and certificate provided), and registration can be done in person, by telephone, by email, or by social media. There are fees for registration, competency test for each competency level, and competency test for each competency unit in each level (applicable only when failing competency unit in level competency test). The first competency test cannot be paid in installment by competency unit.

- Recognition from the government and the society cannot offhandedly arise without the records managers conveying the knowledge about the profession and making controlled effort through professional association to convey the intention to other parties. The controlling attempt can be carried out from and through independent association of professional record managers. Hence, the exchange activities can be carried out in the agreement to give recognition mutually. The development of independent professional association and the acknowledgement to the profession is the institutionalization of the profession itself.

- The changing information technology environment makes it imperative that arsiparis and records managers develop a vision of the future of their professions, stake out conceptually and practically what they bring to the organization and use of electronically recorded information, and initiate dialog with the larger information-handling community (Dollar, 1993).

- Record integrity, record disposition, and record accessibility over time, is linked into a single unifying theme: the importance of contextual relations of electronic records. Arsiparis and records managers should participate in the design of metadata systems to ensure that they contain the contextual information essential for a full understanding of records and record systems. Arsiparis and records managers must play an active role in sharing with other users, standards developers, and information technology vendors, about the importance of supporting technology tools that facilitate access to records over time. The two are in an enterprise that using essentially the same methods and best practices, and technologies to manage the records of organizations (Williams, 2013).

- The core competencies (knowledge and skills) required by record manager practitioners/professionals are as important as the other personal skills required in the workplace (Xiaomi, 2003).

- The personal skills include the skills, attitudes and actions that enable employees to communicate and get along well with others in the workplace and make appropriate decisions when necessary.

This is achieved by ensuring the highest ethical standards are maintained, with the highest quality leadership. Demonstrated compliance with workplace and professional code of conduct and the organization's ethical statements will contribute towards establishing credibility and integrity of a professional record manager.

\subsection{Record Managers and Arsiparis as Agencies of Organization Controlling Functions}

Tannenbaum (1956) summarizes views of modernists about organization control. He says that organization is control. A social organization is an order to human individual 
interactions. Control process helps human behavior to stay focus and sustain it in order to adjust with the organization plan. Organization needs special adjustments as the integration of different activities. This is the function of control to bring adjustments into the requirements of and goals of an organization. Some coordination and orders are created from different interests and diffused potential behavior of the members is the main parts of the functions of control.

Control is one of the managerial aspects besides other managerial functions such as planning, organizing, staffing, and leadership. Nowadays, organizational control has become an important aspect of finance, accountant, and management of information system (Hatch, 2006), which organizations in Indonesia rely on for transparence and accountability. Control is an abstract notion of organization and also the reverse of organization itself. Control and organization is manifested into the form of physical materialization by the by-products of interactions and activities which have been performed as long as the organization exists. The physical materialization or control and organization as its by-product may be said records of organizations.

In the theories of modern organization, organization control defines as a mechanism of the implementation of a strategy. This kind point of view has been criticized by postmodernists as a tool of legitimate which blur influences of the power of managerial and politics. It is possible to think that control looked up as one of organization culture even though this modernist view is being disagreed by the symbolic-intrepretivism. This control perspective is being questioned moreover by the critics come from perspective that sees control as an ideological position which has been clarified by considerations from relationships between control and autonomy within different types of organizations.

Record manager can be said being in the position of performing the function of controlling organization existence and wellbeing. This position of record managers is actually being seen and recognized by the principal of corporations. Record managers are one kind of personals that looked up as important to the operation of organizations and reaching goals. Thus, record managers themselves, in the organizations are tools of control and evolved by controls of themselves.

Control for organization can be seen from the look of investor and external stakeholder such as insurance, creditor, and potential investor. Theory of agency gives the main concern to relationship between the owner or principal and manager or agents. Managers are called agents to indicate that they supposed to act in the interests of owner or principal rather than their own interests. Agency problem involve risks when agents perform their jobs for the sake of their own interests rather than the interests of their principal. Agency as theory gives focus on the way of controlling behavior of agents in order to ensure that the interests of principal are protected. Even though agency is explained in term of relationships between owner or principal of corporation and their managers whom they hired to act under their interests, this theory may be generalized to the relations between lower manager level and sub-ordinate.

Agent interests are transferred into the position of equity with the interest of their principal by control which has been stated in the organization. Agents will work on the interest of principal when they are fulfilling the requirement of their contract. This is the same as control specifically is the measurement and promises of achievements. It will be solved by the award to agents whom have found their goals achieved, based on the operations of activities for the interests of principal. The problem of interest between principal and agent taking care by contracts whereas principal delegates it to agents to reach the values which they both compromise. 
Agents are hired by the principals because of they cannot and would not present continuously in the acts of protecting their interests themselves. However, because of the absent of principal there is opportunity for the "opportunism" which come from agents when they do not perform their duties with responsibility. In another words, it is assumed that agent cannot always rely on performances which have been agreed, sometimes they make mistake.

The writer defines arsiparis in term of controlling of organization in the high level organization as arsiparis performing the organization functional aspect under the guidance of ANRI as the laison office of government. The different between record managers and arsiparis in the context of control and agency that record managers surely have independency and democracy on their own selves on performing their jobs - they have a kind of hegemony of their competence. Arsiparis perform the works under instructions of the government authority as arsiparis is to support the operation of government institutions in the big frame work of government structure.

The discussion provides the result that arsiparis as well as record manager and archivist may be likely considered as two ways of managing organization document based on provenance and original order principals. They are all important skilled persons for organizations, and let them play the performances in their own tracks in harmony.

\section{CONCLUSION}

Arsiparis in Indonesia, become the means of supporting man-power for the state to run its administration activities in spite of the professionals that act as agents and run an agency through their profession. It is reasonable based on the government policy which focused on archives as institution. The formation of independent record manager individuals with professionalism is needed to be able to enter industrial markets, since professionalism determines career development which complies with neo-liberal model. Legitimacy from the government, in the form of record manager profession certification, overcomes the gap between archivist and those whom are called document controller as well as records specialist. The formation of an institution of hybrid professional record manager profession accommodates as troubleshooter for differences between arsiparis and professional record managers. The hybrid and independent institution is a combination of arsiparis and hierarchical record manager competencies. The product of the developed program is a competency frame of independent and legitimate record manager profession, which is beneficial and useful for the people of Indonesia in the field of records and archives management.

Record managers may be called agents whom are doing agency in the controlling function of organization. This framework may also be seen in the arsiparis when arsiparis is seen as self in the context of agency. Then, the strategy for all to solve the different and to mediate the two is the acceptance and recognition through an institution of professional under the regulator of governance of government as the highest organization of Indonesia. The institution of profession is also the controlling notion in the organizations in term of agency, governance, and government. I suggest ANRI would accommodate the regulation concerning the constitution in 2009, enhance to grow the development of the independence professional association in the records for the sake of citizens of Indonesia and the union of the nation. 


\section{ACKNOWLEDGEMENT}

I would like to thank the "record managers" that willingly becoming informants and accept the researcher as part of their everyday life. This paper is founded by hibah PPUPT 2018 Indonesia. 


\section{REFERENCES}

ARMA/American Records Manager Association International. 2007. Records and Information Management Core Competencies. Lenexa: ARMA.

Bettington, Jackie. 2008. Keeping Archives. Canberra: Australian Society of Archivists.

Chevalier, J.M. \& Buckles, D.J. 2013. Participatory Action Research: Theory and Methods for Engaged Inquiry. London: Routledge.

Dollar, Charles M. 1993. Archivists and Records Managers in the Information Age. Archivaria, 21-30. At https://doi.org/loc?.

Gogolou, Christina, \& Efi Dimopoulou. 2015. Land Administration Standardization for the Integration of Cultural Heritage in Land Use Policies. Land Use Policy. https://doi.org/10.1016/j.landusepol.2015.01.029.

Greenwood, Royston, Roy Suddaby, \& C. R. Hinings. 2002. Theorizing Change: The Role of Professional Associations in the Transformation of Institutionalized Fields. Academy of Management Journal. https://doi.org/10.2307/3069285.

Guillén, Mauro F. 2001. Is Globalization Civilizing, Destructive or Feeble? A Critique of Five Key Debates in the Social Science Literature. Annual Review of Sociology, 27: 235-60. https://doi.org/10.1146/annurev.soc.27.1.235.

Hatch, Mary Jo. 2006. Organization Theory. Modern, Symbolic, and Postmodern Perspectives. Oxford: Oxford University Press.

Leontjew, A. 1979. Tätigkeit Bewußtsein Persönlichkeit. Berlin.

Lewin, K. 1946. Action research and minority problems, in G.W. Lewin (Ed.) Resolving Social Conflicts. New York: Harper \& Row.

McKemmish, Sue, Shannon Faulkhead, \& Lynette Russell. 2011. Distrust in the Archive: Reconciling Records. Archival Science. https://doi.org/10.1007/s10502-011-9153-2.

O’Toole M. James \& Cox J. Richard. 2008. Understanding Archives \& Manuscripts. Chicago: Society of American Archivists.

Rahman, Md. A. 2012. Some Trends in the Praxis of Participatory Action Research. London: Sage.

Reason, P. \& Bradbury, H. 2008. The Sage Handbook of Action Research: Participative Inquiry and Practice. California: Sage.

Tannenbaum, Arnold S. 1956. Control Structure and Union Functions. American Journal of Sociology 61, No.6, May, 536-545. https://doi.org/10.1086/221846.

Williams. 2013. Managing Electronic Records: Methods, Best Practices, and Technologies. New Jersey: Wiley.

Xiaomi, An. 2003. An Integrated Approach to Record Management. The Information Management Journal. 